
Kidney
Bloód Pressure
Research

Kidney Blood Press Res 2013;37:240-251

\title{
Modeling of Oxidized PTH (OxPTH) and Non-oxidized PTH (n-oxPTH) Receptor Binding and Relationship of Oxidized to Non-Oxidized PTH in Children with Chronic Renal Failure, Adult Patients on Hemodialysis and Kidney Transplant Recipients
}

\author{
Berthold Hocher ${ }^{a}$ Dominik Oberthür ${ }^{b, i} \quad{\text { Torsten Slowinskic }{ }^{c} \text { Uwe Querfeld }}^{d}$ \\ Franz Schaefere Anke Doyon ${ }^{\mathrm{e}}$ Martin Tepel ${ }^{f}$ Heinz J. Roth ${ }^{g}$ Hans J. Grön ${ }^{\text {h }}$ \\ Christoph Reichetzeder $^{\mathrm{a}} \quad$ Christian Betzel $^{\mathrm{b}} \quad$ Franz P. Armbruster $^{\mathrm{h}}$
}

\begin{abstract}
anstitute of Nutritional Science, University of Potsdam, Potsdam-Rehbrücke, Germany; 'Institute of Biochemistry and Molecular Biology, Laboratory for Structural Biology of Infection and Inflammation, University of Hamburg, Hamburg, Germany; 'Department of Nephrology, Charité-Mitte, Berlin,

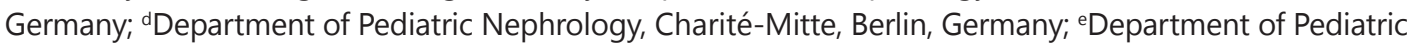

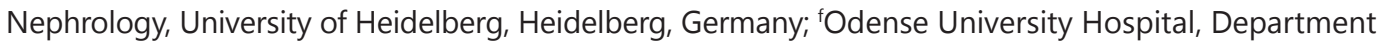
of Nephrology, and Institute of Clinical Research, University of Southern Denmark, Odense, Denmark; 9Department of Endocrinology/Oncology, Limbach Laboratory, Heidelberg, Germany; IImmundiagnostik AG, Bensheim, Germany; 'Center for Free-Electron Laser Science, Deutsches Elektronen-Synchrotron (DESY), Hamburg, Germany
\end{abstract}

\section{Key Words}

n-oxPTH • Chronic Renal Failure • Kidney Transplantation • Hemodialysis • Oxidation • PTH • Chronic Renal Failure in Children

\begin{abstract}
Background: The biological properties of oxidized and non-oxidized PTH are substantially different. Oxidized PTH (oxPTH) loses its PTH receptor-stimulating properties, whereas nonoxidized PTH (n-oxPTH) is a full agonist of the receptor. This was described in more than 20 well published studies in the $1970^{\mathrm{s}}$ and $80^{\mathrm{s}}$. However, PTH oxidation has been ignored during the development of PTH assays for clinical use so far. Even the nowadays used third
\end{abstract}




\section{Kidney Blood Pressure Research}

Kidney Blood Press Res 2013;37:240-251

\begin{tabular}{l|l}
\hline DOI: 10.1159/000350149 & (C) 2013 S. Karger AG, Basel
\end{tabular}

Published ontrne: July 14, 2013

www.karger.com/kbr

Hocher/Oberthür/Slowinski/Querfeld/Schaefer/Doyon/Tepel/Roth/Grön/Reichetzeder/ Betzel/Armbruster: Non-oxidized PTH in patients with chronic renal failure

generation assay systems do not consider oxidation of PTH. We recently developed an assay to differentiate between oxPTH and n-oxPTH. In the current study we established normal values for this assay system. Furthermore, we compare the ratio of oxPTH to n-oxPTH in different population with chronic renal failure: 620 children with renal failure stage 2-4 of the 4C study, 342 adult patients on dialysis, and 602 kidney transplant recipients. In addition, we performed modeling of the interaction of either oxPTH or n-oxPTH with the PTH receptor using biophysical structure approaches. Results: The children had the highest mean as well as maximum n-oxPTH concentrations as compared to adult patients (both patients on dialysis as well as kidney transplant recipients). The relationship between oxPTH and n-oxPTH of individual patients varied substantially in all three populations with renal impairment. The analysis of n-oxPTH in 89 healthy control subjects revealed that n-oxPTH concentrations in patient with renal failure were higher as compared to healthy adult controls $(2.25$-fold in children with renal failure, 1.53-fold in adult patients on dialysis, and 1.56-fold in kidney transplant recipients, respectively). Computer assisted biophysical structure modeling demonstrated, however, minor sterical- and/or electrostatic changes in oxPTH and n-oxPTH. This indicated that PTH oxidation may induce refolding of PTH and hence alters PTH-PTH receptor interaction via oxidation induced three-dimensional structure alteration of PTH. Conclusion: A huge proportion of circulating PTH measured by current state-of-the-art assay systems is oxidized and thus not biologically active. The relationship between oxPTH and $\mathrm{n}$-oxPTH of individual patients varied substantially. Non-oxidized PTH concentrations are 1.5 - 2.25 fold higher in patients with renal failure as compared to health controls. Measurements of n-oxPTH may reflect the hormone status more precise. The iPTH measures describes most likely oxidative stress in patients with renal failure rather than the PTH hormone status. This, however, needs to be demonstrated in further clinical studies.

Copyright (C) 2013 S. Karger AG, Basel

\section{Introduction}

There is no doubt that PTH plays a pivotal role in the pathogenesis of cardiovascular morbidity and mortality of patients with chronic kidney disease. Moreover PTH is also a key hormone controlling bone metabolism [1-4]. The key role of PTH for the health of patients with advanced stages of renal failure such as end-stage renal failure with the need for renal replacement therapy (dialysis) is clearly reflected by the U-shaped relationship between all-cause mortality and PTH concentrations seen in large observational studies [14]. Low PTH concentrations as well as too high PTH concentrations in patients on dialysis (diabetics and non-diabetics) are associated with excess mortality [1]. PTH secretion is controlled by a variety of factors acting on the parathyroid gland, namely the chief cells of this gland: ionized calcium, 1,25 (OH)2 vitamin D and FGF23 are the so far known key factors controlling the synthesis and secretion of PTH by the chief cells of the parathyroid gland [1-4]. Since PTH concentrations are clearly associated with mortality in patients suffering from chronic renal failure and since the PTH concentrations are at least partially changeable in response to alterations of the key regulators or drugs that influence the key regulators, national as well as international academic nephrology societies have established guidelines for target PTH concentrations in order to keep the patient in the "valley of survival" within the U-shaped PTH mortality curve. Such guidelines were, for example, established by the Kidney Disease Improving Global Outcomes (KDIGO) initiative and recommend repeated measurements in daily practice to monitor absolute concentrations and trends of changes of PTH [5]. However, PTH is a particularly tricky hormone to measure as stated in a very recent editorial [6]. Scientists have fought worldwide for good assays since decades. Initially RIA`s were used. These RIA`s used antibodies recognizing small parts of the entire 84-aminoacid hormone. Thus they detected in reality a mixture of real intact PTH and biologically inactive 


\section{Kidney Blood Pressure Research}

Kidney Blood Press Res 2013;37:240-251

\begin{tabular}{l|l}
\hline DOI: 10.1159/000350149 & C 2013 S. Karger AG, Basel
\end{tabular}

Published onlıne: July 14, 2013

www.karger.com/kbr

Hocher/Oberthür/Slowinski/Querfeld/Schaefer/Doyon/Tepel/Roth/Grön/Reichetzeder/ Betzel/Armbruster: Non-oxidized PTH in patients with chronic renal failure

PTH fragments [6]. A huge step forward was the introduction of the sandwich technology to measure PTH. In this assay one antibody linked to a solid phase binds to one end of the PTH molecule, whereas a second antibody linked to a detection system binds the other end of the PTH molecule [6]. This ensures that mainly intact full-length PTH is detected. However, this way of detecting PTH also has major shortcomings. A recent study compared the main currently established assays in daily clinical laboratory routine using the sandwich technology by comparing results from different assays obtained from the same individuals. They detected an unacceptably high variability between assay results from the same patient (up to a factor of 4) [7]. Despite the high variability of results obtained from the same patient, there is another issue that was simply not considered when measuring PTH for more than 20 years now [8-11]. Cell culture experiments as well as whole animal experiments in a lot of laboratories worldwide indicate that only non-oxidized PTH activates the PTH receptor and is biologically active [8-11]. PTH can be oxidized at its methionine residues at position 8 and 18 [8-11]. The receptor binding domain is also located in this region of the PTH molecule. All currently used sandwich ELISAs for PTH will detect the entire PHT irrespective of its oxidation status. We recently developed an assay system using antibodies against oxidized forms of PTH that can differentiate between oxidized PTH (oxPTH) and non-oxidized PTH (n-oxPTH) [12]. Initial studies suggest that patient's outcome in term of mortality is different when considering oxPTH or n-oxPTH [13]. Aim of the current study was thus to compare the ratio of oxPTH to n-oxPTH in different populations with chronic renal failure: 620 children with renal failure stage 2-4 of the 4C study population, 342 adult patients on dialysis, and 602 kidney transplant recipients. Since the differences in biological activity of oxPTH and $\mathrm{n}$-oxPTH was just analyzed so far in cell culture systems and experimental animal models, we additionally performed modeling of the interaction of either oxPTH or n-oxPTH with the PTH receptor using modern three-dimensional biophysical structure approaches analyzing the interaction of a hormone with its receptor. Furthermore we established normal values of $\mathrm{n}$-oxPTH and oxPTH in 89 healthy subjects and reviewed the literature coming from various groups worldwide analyzing the in vitro and in vivo differences of oxPTH and n-oxPTH.

\section{Material and Methods}

\section{PTH-Receptor Binding Modeling}

For modeling and to identify structural and functional differences between native n-oxPTH and oxidized PTH (oxPTH) coordinates of a PTH fragment (amino acid residues 1-34, PTH $^{1-34}$ ) were retrieved from the Protein Data Base (PDB) [14]. In the PDB 14 structures of PTH fragments can be found of which 12 were determined by NMR techniques and two by X-ray diffraction. The structure with the best resolution (PDB-accession code: 1ET1, Resolution: 0.9 Angström )[15] was selected for modeling with the software SYBYL-X [16]. In SYBYL-X all solvent molecules were removed, hydrogen was added and, for modeling of oxPTH, all four methionine residues in the PTH fragment dimer were transformed into methionine sulfoxide (SME, oxidized form of methionine). Then, for n-oxPTH and oxPTH, the charge distribution of the dimer was calculated, followed by energy minimization applying a Tripos force field with Gasteiger-Hückel charges, an NB cutoff radius of $8 \AA$, a fixed dielectric constant of 20 and maximum of 10,000 iterations subject to a termination gradient of $0.1 \mathrm{kcal} /(\mathrm{mol} \bullet \AA ⿻)$ )).

To assess differences in the interaction of n-oxPTH and oxPTH with the PTH receptor PTH1R, an analogous procedure was carried out. The coordinates of an X-ray diffraction derived structure of a PTH fragment (residues 15-34, PTH $^{15-34}$ ) in complex with GPCR PTH1R [17] were retrieved from the PDB (Accession code: 3C4M). Modeling with SYBYL was carried out as described above. To assess whether oxidation of the second methionine residue in PTH (Met8) has effects on the PTH:receptor interaction, m-oxPTH ${ }^{15-34}$ in the complex was replaced by PTH $^{1-34}$ applying the LSQ superposition function of WinCoot [18] followed by removal of n-oxPTH ${ }^{15-34}$ chains from the merged PDB-file with the PDBset program of CCP4 [19]. Modeling with Sybyl was carried out as described above. 


\section{Kidney Blood Pressure Research}

Table 1. Baseline characteristics of 620 children with chronic renal failure stage $2-4$ at study entry participating in the Cardiovascular Comorbidity in Children with Chronic Kidney Disease (4C) study.

\begin{tabular}{lcc}
\hline & Mean +/- SD & Range \\
\hline Age (years) & $12.13+/-3.32$ & $5.51-18.13$ \\
Gender (female/male) & $216 \mathrm{f} / 404 \mathrm{~m}$ & \\
Serum cystatin $(\mathrm{mg} / \mathrm{dL})$ & $2.85+/-0.91$ & $0.77-7.07$ \\
Serum calcium $(\mathrm{mmol} / \mathrm{L})$ & $2.21+/-0.24$ & $0.94-2.85$ \\
Serum phosphorus $(\mathrm{mmol} / \mathrm{l})$ & $1.54+/-0.38$ & $0.43-3.93$ \\
Intact PTH $[\mu \mathrm{g} / \mathrm{l}]$ & $163.52+/-172.35$ & $5.00-1535.00$ \\
oxPTH $[\mu \mathrm{g} / \mathrm{l}]$ & $147.10+/-160.41$ & $1.57-1388.40$ \\
$\mathrm{n}-\mathrm{oxPTH}[\mu \mathrm{g} / \mathrm{l}]$ & $17.35+/-14.61$ & $0.01-146.60$ \\
iPTH/n-oxPTH Ratio & $8.75+/-3.49$ & $1.00-22.07$ \\
oxPTH/n-oxPTH Ratio & $7.75+/-3.49$ & $0.71-21.07$ \\
\hline
\end{tabular}

The resulting models were analyzed with the molecular graphics software PyMOL [20] the PDBsum webserver [21] and the program Contact from the CCP4 suite[6] to assess the similarities and differences of protein-protein interaction in the complex.

Measuring of oxPTH, $n$-oxPTH and intact PTH in children with renal failure stage 2-4, adult patients on dialysis, and kidney transplant recipients

PTH assay system. The intact-PTH electrochemiluminescence immunoassay (ECLIA; Roche PTH, Intact [iPTH]) uses a biotinylated monoclonal antibody, which reacts with amino acids 26-32, and a capture ruthenium-complexed monoclonal antibody, which reacts with amino acids 55-64. The determinations were performed on Roche Modular E $170^{\circledR}$. Human samples were measured either directly (named iPTH) or after removal of oxidized PTH by a column with removing oxidized PTH using anti-hOxPTH monoclonal antibodies as recently described in detail [12].

\section{Study populations}

Children with renal failure stage 2-4 of the 4C study. The Cardiovascular Comorbidity in Children with Chronic Kidney Disease (4C) study is a prospective observational cohort study [22] in pediatric CKD patients. Inclusion criteria are age 6 to 17 years and estimated GFR 10 to $45 \mathrm{ml} / \mathrm{min}$ per $1.73 \mathrm{~m}^{2}$. Exclusion criteria are the presence of active systemic vasculitis, renal vascular anomalies, coexisting primary cardiovascular anomalies, and anomalies of the limbs preventing diagnostic procedures. Children who reach end-stage renal disease will be continuously followed while on renal replacement therapy. We analyzed 620 children; basic demographic data are given in Table 1.

Adult patients on dialysis. To determe the ratio of either iPTH or oxPTH to n-oxPTH in hemodialysis patients we performed a prospective cohort study in 342 hemodialysis patients from different chronic dialysis centers in Berlin, Germany. The eligibility criteria aimed to be broad and included all adult patients on hemodialysis treatment due to end-stage chronic kidney disease stage 5 and presence of informed consent. Informed consent from each patient and ethical approval by the local ethics committee were obtained. All of the patients were routinely dialyzed for 4 to 5 hours three times weekly using biocompatible membranes. Blood flow rates were 250 to $300 \mathrm{~mL} / \mathrm{min}$, dialysate flow rates were $500 \mathrm{~mL} / \mathrm{min}$, dialysate conductivity was $135 \mathrm{mS}$. Predialysis blood samples were taken at study entry. Blood was collected immediately before the start of the hemodialysis session.

Kidney transplant recipients. We included 602 patients presenting to the transplant clinic CharitéMitte, Berlin, Germany, between August and December 2012. The patients gave their informed consent for analysis. The study protocol was approved by the local ethics committees. Demographic data for recipients and donors (cold ischaemia time, HLA mismatches, donor's age, panel reactive antibodies, recipient's age and sex, and transplant survival) were extracted from hospital records. During routine visits, blood was collected stored at $-20^{\circ} \mathrm{C}$ until use.

Healthy controls. Blood was taken from 89 randomly selected healthy blood donors at the Transfusion Center, University Medical Center, Johannes Gutenberg-University Mainz, Germany. Blood taking was approved by the local ethic board of the university. 


\section{Kidney \\ Blood Pressure Research}

Fig. 1. The modeled complex of receptor PTH1R (displayed as surface) and $\mathrm{PTH}^{15-34}$ (displayed as cartoon plot. $\mathrm{PTH}^{15-34}$ : turquois. ${ }^{15-34}$ : green) aligned with the oxidized complex. Met18 (oxidized and native) faces away from the interaction region.

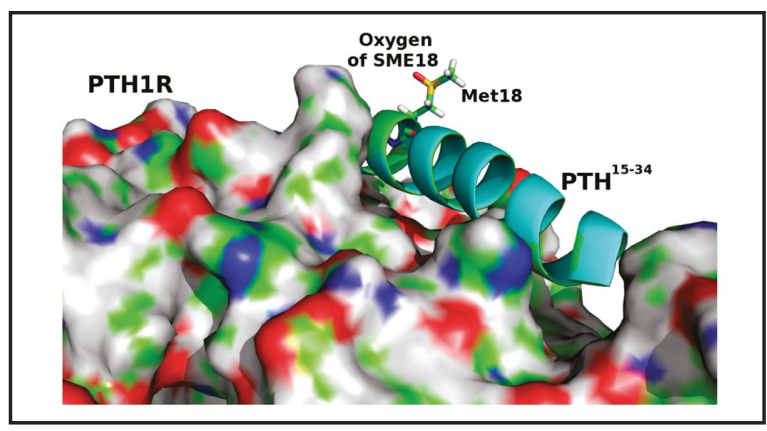

Fig. 2. The modeled complex of receptor PTH1R (displayed as cartoon, native: orange and oxidized: purple) and $\mathrm{PTH}^{1-34}$ (displayed as cartoon plot. n-oxPTH ${ }^{1-34}$ : red. oxPTH ${ }^{1-34}$ : blue) aligned with the oxidized complex. It can be clearly seen that both Met8 and Met18 (oxidized and native) face away from the PTH receptor interaction region.

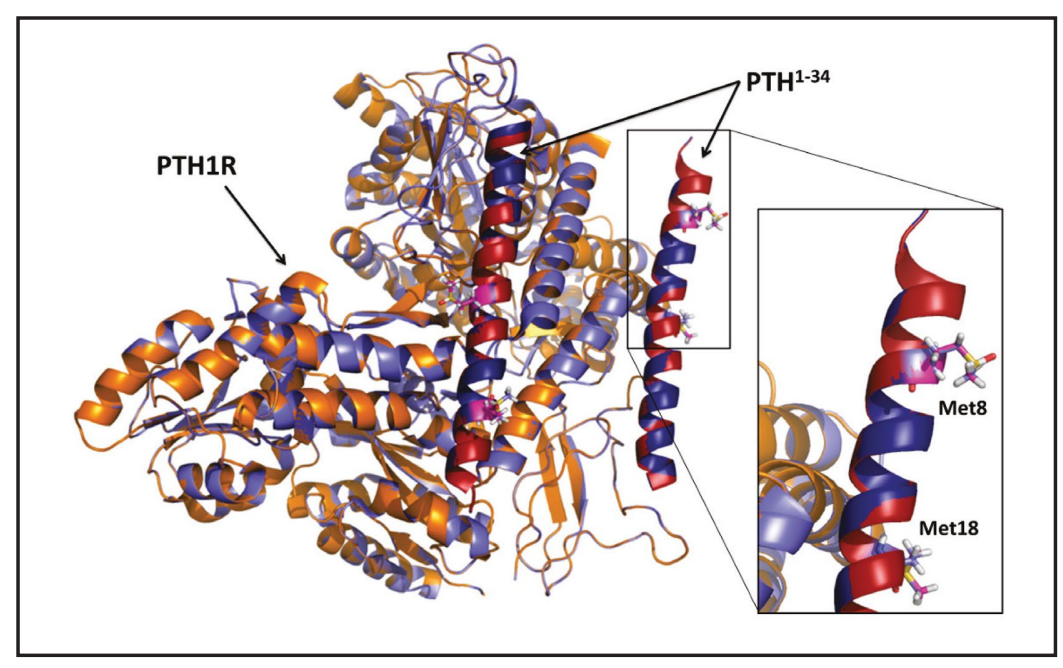

\section{Results}

\section{PTH Receptor Binding Modeling}

To investigate the PTH-receptor interaction, the PTH1R GPCR structure (PDB-accession code: 3C4M) [17] was chosen. The PTH-receptor complex contains two receptor molecules (chain A and B), each with one bound $\mathrm{PTH}^{15-34}$ molecule (chain C and D)[21]. No Met residues (both native and oxidized) are involved directly in receptor-PTH ${ }^{15-34}$ interaction. Whilst most of the residues of $\mathrm{PTH}^{15-34}$ are involved in ligand-receptor binding (16 of 21), all atoms of the Met18 side chain, in the native state as well as in the oxidized model, have a distance of more than $5 \AA$ to the closest atom of the receptor.

The oxidized and native side chains of Met18 of $\mathrm{PTH}^{15-34}$ are located both on the side the $\alpha$-helix opposite to the PTH-receptor interaction region. In the case of oxPTH ${ }^{15-34}$, there are 13 hydrogen bonds present between chain $\mathrm{A}$ and $\mathrm{C}\left(\mathrm{PTH}^{15-34}: 13\right)$ and 12 between chain $\mathrm{B}$ and D (PTH $\left.{ }^{15-34}: 12\right)$. The Root Mean Square Deviation (RMSD) between the two models calculated by the align algorithm of PyMol is $0.005 \AA$. An overlay of oxidized and native model is shown in Figure 1.

It is know that oxidation of residue Met8 of PTH plays an important role in biological activity [23-25]. Chain A of PDB-model 1ET1 was superimposed onto Chain C and D of the PTH1R-PTH ${ }^{15-34}$ complex applying the LSQ algorithm of WinCoot [18]. After modeling, the complex with oxPTH ${ }^{1-34}$ was compared to the one bearing the native $\mathrm{PTH}^{1-34}$ [21]. Less residues of oxPTH ${ }^{1-34}$ compared to oxPTH ${ }^{15-34}$ are involved in interaction with PTH1R (13 and 14 of 34 compared to 15 of 21). Neither oxidized Met8 nor n-oxMet18 are involved in receptor interaction. The PTH-receptor complexes of n-oxPTH ${ }^{1-34}$ and oxPTH $^{1-34}$ show no differences regarding involved residues, interface area and number of hydrogen bonds. The Root Mean Square Deviation (RMSD) between the two models calculated by the align algorithm of PyMol is $0.002 \AA$ (see Figure 2). 


\section{Kidney Blood Pressure Research}

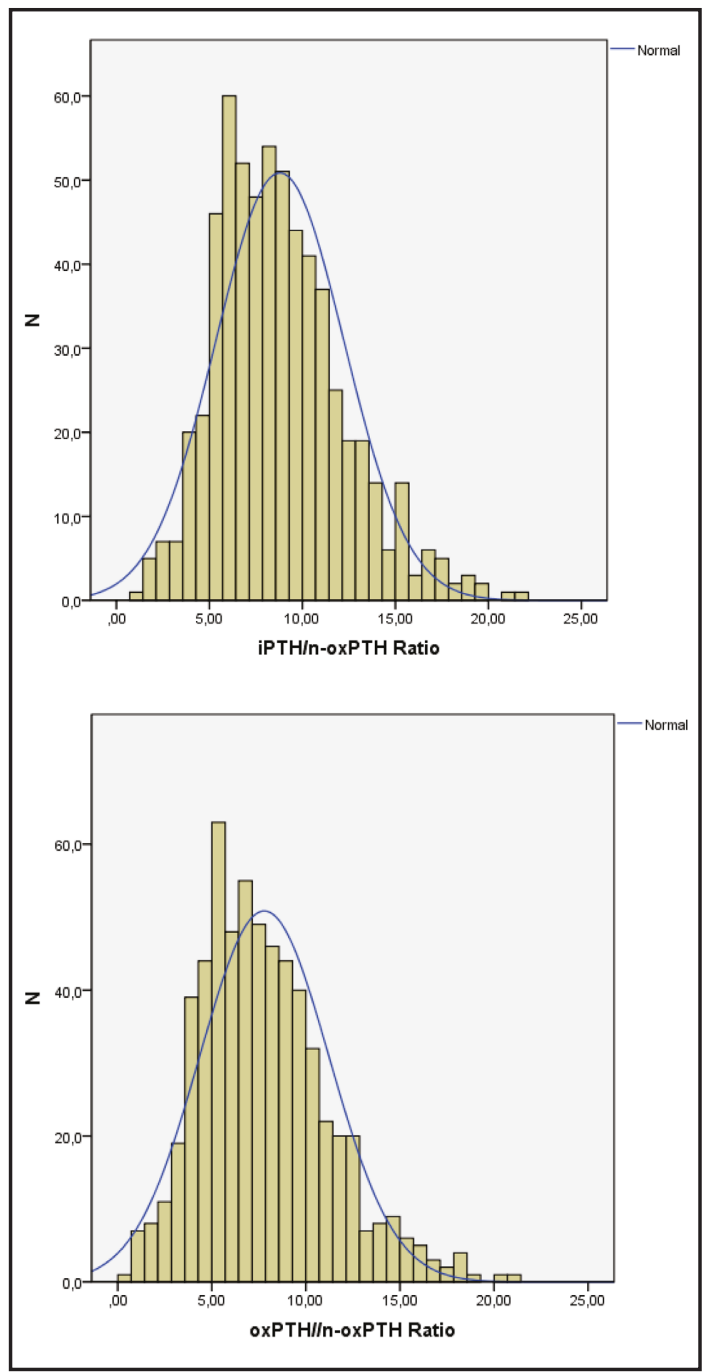

Fig. 3. Histogram showing the ratio of either $\mathrm{iPTH}$ to n-oxPTH (top) and oxPTH to n-oxPTH (bottom) in 620 children with chronic renal failure stage $2-4$ at study entry participating in the Cardiovascular Comorbidity in Children with Chronic Kidney Disease (4C) study.
Hocher/Oberthür/Slowinski/Querfeld/Schaefer/Doyon/Tepel/Roth/Grön/Reichetzeder/ Betzel/Armbruster: Non-oxidized PTH in patients with chronic renal failure

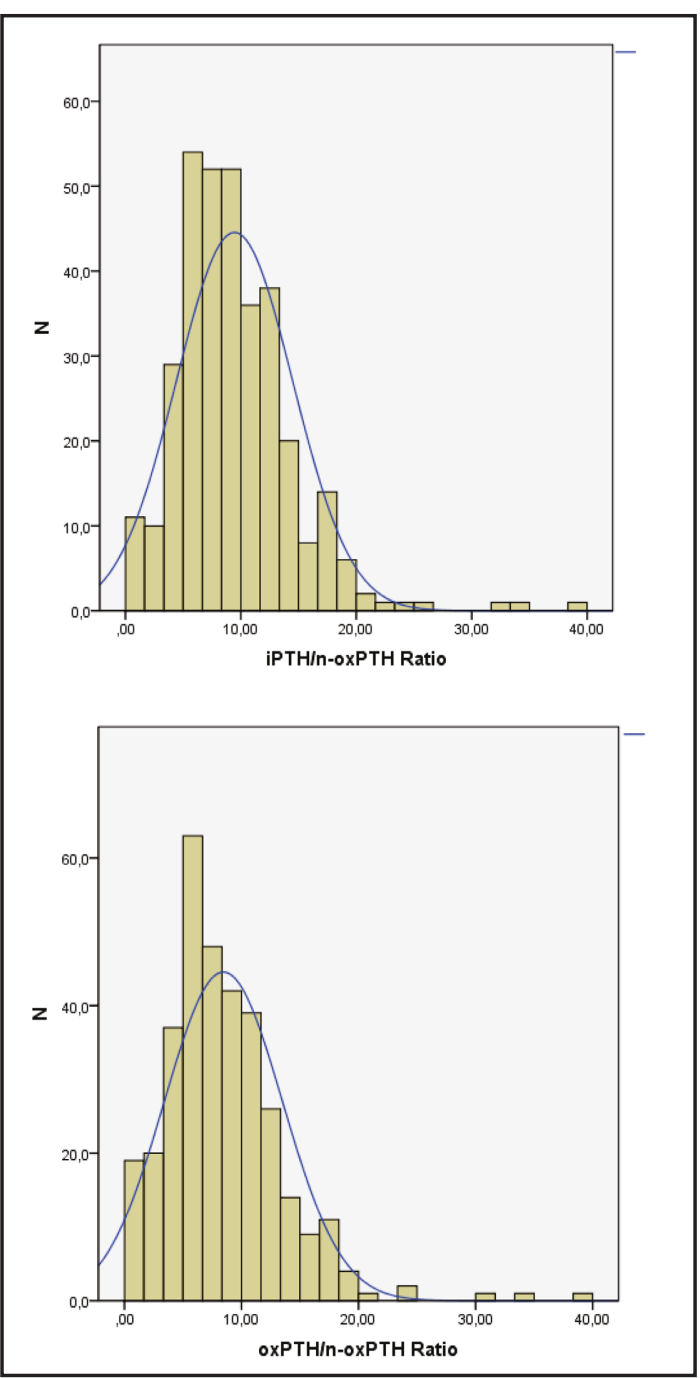

Fig. 4. Histogram showing the ratio of either iPTH to n-oxPTH (top) or oxPTH to n-oxPTH (bottom) ratios in 342 patients with end stage renal disease on hemodialysis.

\section{Clinical Data - Study populations}

Children with renal failure stage 2-4 of the 4C study [22]. We analyzed plasma probes from 620 children with chronic renal failure, for clinical data see Table 1 . The iPTH/n-oxPTH ratio was $8.75+/-3.49$. The oxPTH/n-oxPTH ratio was 7,75 +/- 3.49 (see also Figure 3). The mean n-oxPTH concentration was $17.35+/-14,61 \mu \mathrm{g} / \mathrm{l}$ with a range from $0.01-146,60 \mu \mathrm{g} / \mathrm{l}$. The plasma concentrations of n-oxPTH, oxPTH, and iPTH did not depend on gender but on age of the analyzed children(Pearson Correlation: $0.098: \mathrm{p}=0.015$ ).

Adult patients on dialysis. We analyzed plasma probes of 342 adult patients with endstage renal disease on dialysis (for clinical data see Table 2). The iPTH/n- ratio was 9.45 $+/-5.04$. The oxPTH/n-oxPTH ratio was 8.45 +/- 5.04 (see also Figure 4). The mean n-oxPTH concentration was $11,77+/-20.88 \mu \mathrm{g} / \mathrm{l}$ with a range from $1.20-300.70 \mu \mathrm{g} / \mathrm{l}$. 


\section{Kidney Blood Pressure Research}

Table 2. Baseline characteristics of the 342 end-stage renal disease patients on hemodialysis

Table 3. Baseline characteristics of 602 kidney transplant recipients.

Table 4. Baseline characteristics of 89 healthy controls.

\begin{tabular}{|c|c|c|}
\hline & Mean +/-SD & Range \\
\hline Age (years) & $64.7+/-13.37$ & $22-92$ \\
\hline Gender (female/male) & $117 \mathrm{f} / 225 \mathrm{~m}$ & \\
\hline Body mass index & $25.10+/-4.82$ & $14.2-65.7$ \\
\hline $\mathrm{ktV}$ & $1.21+/-0.21$ & $0.70-1.90$ \\
\hline Serum calcium (mmol/L) & $2.26+/-0.30$ & $0.70-3.80$ \\
\hline Serum phosphorus (mmol/l) & $1.67+/-0.65$ & $0.30-4.10$ \\
\hline Intact PTH $[\mu \mathrm{g} / \mathrm{l}]$ & $105.22+/-160.43$ & $5.00-1854.00$ \\
\hline ox PTH $[\mu \mathrm{g} / \mathrm{l}]$ & $93.83+/-142.02$ & $0.02-1553.30$ \\
\hline n-oxPTH $[\mu \mathrm{g} / \mathrm{l}]$ & $11.77+/-20.88$ & $1.20-300.70$ \\
\hline iPTH/n-oxPTH Ratio & $9.45+/-5.04$ & $1.00-39.38$ \\
\hline oxPTH/n-oxPTH Ratio & $8.45+/-5.04$ & $0.00-38.38$ \\
\hline
\end{tabular}

\begin{tabular}{|c|c|c|}
\hline & Mean +/-SD & Range \\
\hline Age recipient (years) & $55.30+/-14.54$ & $21,04-87.38$ \\
\hline Age donor (years) & $49.99+/-16.04$ & $17.46-85.00$ \\
\hline Gender (female/male) & $233 \mathrm{f} / 369 \mathrm{~m}$ & \\
\hline Cold ischemic time & $10.05+/-7.34$ & $0.08-42.00$ \\
\hline GFR & $44.39+/-18.01$ & $11.00-114.00$ \\
\hline 1.250H Vit D & $96.09+/-54.29$ & $6.30-389.00$ \\
\hline Serum calcium (mmol/L) & $2.48+/-0.19$ & $1.62-3.09$ \\
\hline Serum phosphorus (mmol/l) & $1.51+/-0.39$ & $0.49-3.81$ \\
\hline Intact PTH $[\mu \mathrm{g} / \mathrm{l}]$ & $113.80+/-129.34$ & $1.24-1343.00$ \\
\hline ox PTH $[\mu \mathrm{g} / \mathrm{l}]$ & $101.86+/-117.76$ & $0.01-1219.50$ \\
\hline n-oxPTH $[\mu \mathrm{g} / \mathrm{l}]$ & $12.01+/-12.62$ & $1.20-133.20$ \\
\hline iPTH/n-oxPTH Ratio & $9.4749+/-3.99$ & $1.08-50.58$ \\
\hline oxPTH/n-oxPTH Ratio & $8.47+/-3.98$ & $0.08-49.5$ \\
\hline
\end{tabular}

\begin{tabular}{lcc}
\hline & Mean $+/-$ SD & Range \\
\hline Age (years) & $40.06+/-11.59$ & $20-60$ \\
Gender (female/male) & $45 \mathrm{f} / 44 \mathrm{~m}$ & \\
Intact PTH $[\mu \mathrm{g} / \mathrm{l}]$ & $33.26+/-15.43$ & $13-104$ \\
ox PTH $[\mu \mathrm{g} / \mathrm{l}]$ & $25.55+/-14.37$ & $7.39-89.53$ \\
$\mathrm{n}-\mathrm{oxPTH}[\mu \mathrm{g} / \mathrm{l}]$ & $7.71+/-1.55$ & $5-14$ \\
iPTH/n-oxPTH Ratio & $4.24+/-1.36$ & $2.24-9.67$ \\
oxPTH/n-oxPTH Ratio & $3.24+/-1.36$ & $1.24-8.67$ \\
\hline
\end{tabular}

The plasma concentrations of $\mathrm{n}$-oxPTH (Pearson Correlation: -,127: $\mathrm{p}=0.019$ ), oxPTH (Pearson Correlation: $-0.109: \mathrm{p}=0.045$ ) and iPTH (Pearson Correlation:

$-0.113: p=0.038$ ) correlated with the age of the dialysis patients, whereas gender had no influence on these parameters.

Kidney transplant recipients. We analyzed plasma probes from 602 kidney transplant recipients (for clinical data see Table3). The iPTH/n-oxPTH ratio was $9.4749+/-3.99$. The oxPTH/n-oxPTH ratio was $8.47+/-3.98$ (see also Figure 5). The mean n-oxPTH concentration was $12.01+/-12.62 \mu \mathrm{g} / \mathrm{l}$ with a range from $1.20-133.20 \mu \mathrm{g} / \mathrm{l}$.

The plasma concentrations of $\mathrm{n}$-oxPTH (Pearson Correlation: $0.095 ; \mathrm{p}=0.020$ ), oxPTH (Pearson Correlation: 0.123; $\mathrm{p}=0.003$ ) and $\mathrm{iPTH}$ (Pearson Correlation: 0.121; $\mathrm{p}=0.003$ ) correlated with age.

Concentrations of n-oxPTH in kidney transplant recipients were not gender-dependent. However, iPTH $(122.34 \mu \mathrm{g} / \mathrm{l}$ versus $100.28 \mu \mathrm{g} / \mathrm{l}$; p<0.05) as well as oxPTH $(109.77 \mu \mathrm{g} / \mathrm{l}$ versus $89.35 \mu \mathrm{g} / \mathrm{l} ; \mathrm{p}<0.05$ ) concentrations were higher in male kidney transplant recipients.

Healthy controls. We analyzed 89 blood donors (Table 4). The mean n-oxPTH was $7.71+/-1.55 \mu \mathrm{g} / \mathrm{l}$ with a range of $5-14 \mu \mathrm{g} / \mathrm{l}$. It is of note that healthy controls also have 


\section{Kidney \\ Blood Pressure Research}

Kidney Blood Press Res 2013;37:240-251

DOI: 10.1159/000350149

Published ontIne: July 14, 2013

(C) 2013 S. Karger AG, Basel

www.karger.com/kbr

Hocher/Oberthür/Slowinski/Querfeld/Schaefer/Doyon/Tepel/Roth/Grön/Reichetzeder/ Betzel/Armbruster: Non-oxidized PTH in patients with chronic renal failure

a huge proportion of oxidized PTH (oxPTH) as indicated by the iPTH/n-oxPTH ratio of $4.24+/-1.36$ and oxPTH/n-oxPTH ratio $3.24+/-1.36$, respectively. These ratios are much lower as compared to patients with renal impairment (children with stage 2-4 renal failure, patients on dialysis, and kidney transplant recipients), see above. The analysis of n-oxPTH in healthy control subjects revealed that n-oxPTH concentrations in patients with renal failure were higher compared to healthy adult controls (2.25-fold in children with renal failure, 1.53-fold in adult patients on dialysis, 1.56-fold in kidney transplant recipients).

Additionally, we analysed wheather n-oxPTH might be oxidized ex vivo after blood taking. We therefore took blood from healthy subjects and processed it either immediately after blood taking or 60,120 and 180 min later. Blood was stored during this time at room temperature. The oxPTH/noxPTH ratio nor the n-oxPTH concentration changed over time.

\section{Discussion}

Our study in 620 children with renal failure stage 2-4, 342 adult patients on dialysis, and 602 kidney transplant recipients showed that a huge proportion of circulating PTH as measured by current state-of-the-art assay systems is oxidized. Oxidation of PTH, however, causes loss of biological activity as demonstrated in a lot of independent studies some decades ago. The relationship between

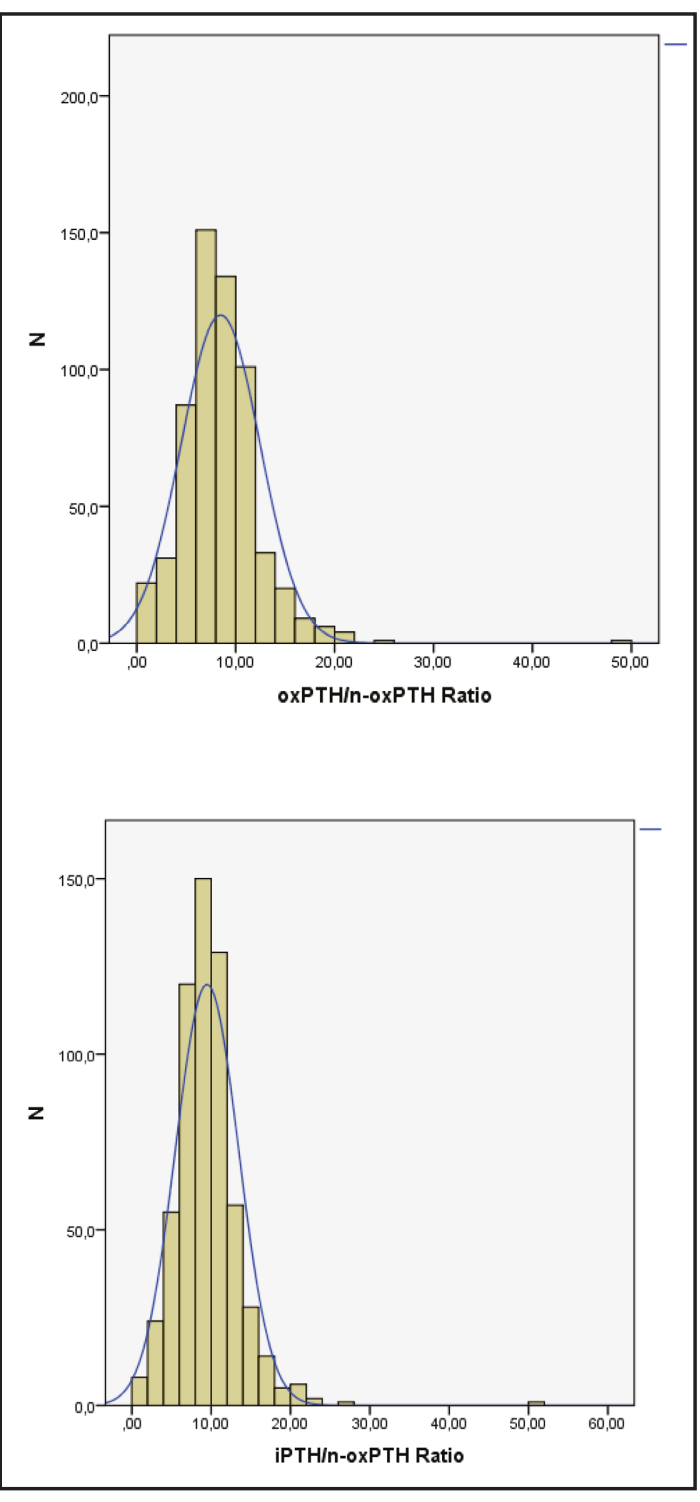

Fig. 5. Histogram showing the ratio of either the iPTH to n-oxPTH (top) or oxPTH to n-oxPTH (bottom) ratios in 602 kidney transplant recipients. oxPTH and n-oxPTH of individual patients varied substantially. Non-oxidized PTH concentrations are 1.5 -2.25-fold higher in patients with renal failure as compared to health controls. The iPTH measures most likely describes oxidative stress in patients with renal failure rather than the PTH hormone status.

\section{Modeling data}

It is clear that n-oxPTH and oxPTH have different biological activities [8-12, 23-47]. In particular, Zull et al. [11] showed by CD-Spectroscopy studies of different fragments of PTH that a) residues 1-34 are required for the activity of PTH, b) oxidation of Met18 is insignificant compared to oxidation of Met8 regarding both activity and (2D) structural changes and c) that oxidation of Met8 leads to significant changes not only of activity but of the secondary structure of PTH as well. Structural data available in the PDB contains only $\mathrm{n}$-oxPTH, moreover the complex with the PTH1R receptor contains only n-oxPTH ${ }^{15-34}$, thus 


\section{Kidney Blood Pressure Research}

Kidney Blood Press Res 2013;37:240-251

\begin{tabular}{l|l}
\hline DOI: 10.1159/000350149 & (C) 2013 S. Karger AG, Basel
\end{tabular}

Published onlıne: July 14, 2013

www.karger.com/kbr

lacking the important Met8. Modeling of $\mathrm{PTH}^{1-34}$ into the PTH-receptor complex addressed the problem of the missing but more important Met8 residue, however the structural changes observed by CD-spectroscopy [23] could not be shown with this simple modeling approach of Methionine oxidation that resulted only in little changes in PTH-receptor interaction. The methionines as such are not directly involved in interaction and are located far away from the interaction region. Oxidation of Methionine neither leads to clashes with neighboring residues nor does it lead to stabilization of PTH or the PTH-receptor complex through vander-Waals forces or hydrogen bonds.

Comparison of our results with the CD-Spectroscopy studies and studies regarding the biological activity imply however that the different levels of activity are due to the refolding of PTH upon oxidation and not directly due to sterical and/or electrostatic changes close to the methionines after oxidation.

Discussion/Review of studies analysis in vitro and in vivo effects of n-oxPTH in comparison to oxPTH.

There is overwhelming evidence that oxPTH and n-oxPTH have completely different biological properties [8-12, 23-48]. Initial studies using classical receptor binding assays demonstrated that oxidized PTH does not bind to the PTH receptor anymore [24-26, 28, 38]. Other studies focused on the generation of the second messenger of PTH-receptor, cAMP. These studies indicated that oxidized PTH - in contrast to non-oxidized PTH - does not stimulate the PTH receptor to generate cAMP [9, 24, 25, 37, 42, 45, 48]. In addition, it was demonstrated that oxidized PTH loses its biological action on smooth muscle cells contraction/vascular effects in tissues like trachea, and aortic rings, and uterus [32, 35, 36, $41,42,45]$. Stimulation of alkaline phosphatase activity in cultured neonatal mouse calvarial bone cells by parathyroid hormone [39] was only seen after incubation with n-oxPTH but not with oxPTH. Other studies demonstrate that only n-oxPTH but not oxPTH is able to regulate calcium and phosphate metabolism [10, 40, 43].

\section{Clinical data}

It is of note that children had the highest mean as well as maximum n-oxPTH concentrations as compared to adult patients (both patients on dialysis as well as kidney transplant recipients). The iPTH concentrations were substantially higher in all 3 patient cohorts (Tables $1-3$ ). The ratios of iPTH to n-oxPTH and oxPTH to n-oxPTH were highly variable in the three cohorts (Figures 3-5) indicating that it is impossible to predict n-oxPTH from iPTH measurements. The iPTH/n-oxPTH ratio as well as the oxPTH/n-ox ratio were normally distributed in all three cohorts (Figures 3-5). Since only n-oxPTH is biologically active (see above), we suggest messuring n-oxPTH for clinical decision making, e.g. the decision to use vitamin D or calcimimetics. Measures of intact PTH mainly reflect oxidative stress-induced protein oxidation and, to a minor extent the PTH status of the patient. However, this hypothesis - also very convincing because of the huge amount of data showing that oxPTH is biologically inactive (see above) - needs confirmation by clinical data. Data showing differences in mortality and bone metabolism like PTH association studies with bone alkaline phosphatase are urgently needed to prove the potential clinical benefit of measuring n-oxPTH.

What was surprising is the fact that, even in healthy controls, the amount of circulating oxidized PTH is high (see Table 4). This raised some questions: First, does oxPTH act not just as a waste product without biological properties in human beings. We speculate that oxPTH may have its own biological impact independent of classical PTH biology. Second, what are the mechanisms leading to oxidation of PTH? What is controlling this process? Is PTH oxidized already in the parathyreoid gland? All these important questions needs to be addressed carefully in the future. The only point that is clear so far is the finding that PTH oxidation is an in vivo process and does not occur ex vivo - means after blood taking. This was clearly proven by our ex vivo stability tests. 


\section{Kidney \\ Blood Pressure Research}

Kidney Blood Press Res 2013;37:240-251

\begin{tabular}{l|l}
\hline DOI: $10.1159 / 000350149$ & (C) 2013 S. Karger AG, Basel
\end{tabular}

Published onlıne: July 14, 2013

www.karger.com/kbr

Hocher/Oberthür/Slowinski/Querfeld/Schaefer/Doyon/Tepel/Roth/Grön/Reichetzeder/ Betzel/Armbruster: Non-oxidized PTH in patients with chronic renal failure

\section{Conclusion}

To sum up, a huge proportion of circulating PTH measured by current state of the art assay systems is oxidized and thus not biologically active. The relationship between oxPTH and n-oxPTH of individual patients varied substantially. Non-oxidized PTH concentrations are 1.5 - 2.25-fold higher in patients with renal failure compared to healthy controls. Measurements of n-oxPTH may reflect the hormone status more precisely. The iPTH measures describes most likely oxidative stress in patients with renal failure rather than the PTH hormone status. However, this hypothesis - although supported by a lot of preclinical studies (see above) - needs to be proven in adequately designed clinical studies in the future. Modeling of n-oxPTH and oxPTH biophysical properties indicated that as indicated by CD spectroscopy experiments [11], the different biological activities of n-oxPTH and oxPTH can only be explained by changes of the overall three-dimensional conformation of PTH upon oxidation.

\section{Conflict of Interests}

FPA: CEO of Immundiagnostik AG, Bensheim, Germany. HJG: Employee of Immundiagnostik AG, Bensheim, Germany. Immundiagnostik AG is currently developing an assay to measure n-oxPTH for clinical use.

\section{Acknowledgements}

We thank the participating patients and healthy volunteers. The establishing of the transplant cohort and the dialysis cohort was supported by a research grant from the university hospital Charité, Berlin, Germany. The 4C Study has been made possible by grants of the KfH Foundation for Preventive Medicine, the European Renal Association - European Dialysis and Transplant Association (www.era-edta.org) and the German Federal Ministry of Education and Research (reference number: 01E00802).

\section{References}

1 Floege J, Kim J, Ireland E, Chazot C, Drueke T, de Francisco A, Kronenberg F, Marcelli D, Passlick-Deetjen J, Schernthaner G, Fouqueray B, Wheeler DC; ARO Investigators: Serum iPTH, calcium and phosphate, and the risk of mortality in a European haemodialysis population. Nephrol Dial Transplant 2011;26:1948-1955.

-2 Torres PA, De Broe M: Calcium-sensing receptor, calcimimetics, and cardiovascular calcifications in chronic kidney disease. Kidney Int 2012;82:19-25.

3 Souberbielle JC, Roth H, Fouque DP: Parathyroid hormone measurement in CKD. Kidney Int 2010;77:93100.

4 Chaykovska L, Tsuprykov 0, Hocher B: Biomarkers for the prediction of mortality and morbidity in patients with renal replacement therapy. Clin Lab 2011;57:455-467.

5 Sprague SM, Moe SM: The case for routine parathyroid hormone monitoring. Clin J Am Soc Nephrol 2013;8:313-318.

6 Garrett G, Sardiwal S, Lamb Ej, Goldsmith DJA: †PTH—A Particularly Tricky Hormone: Why Measure It at All in Kidney Patients? Clin J Am Soc Nephrol 2013;8:299-312.

7 Almond A, Ellis AR, Walker S: Current parathyreoid hormone immunoasssays do not adequately meet the need of patients with chronic kidney disease. Ann Clin Biochem 2012;49:63-67.

$>8$ Vogt W: Oxidation of methionyl residues in proteins: tools, targets, and reversal. Free Radic Biol Med 1995;18:93-105. 


\section{Kidney \\ Blood Pressure Research}

-9 Galceran T, Lewis-Finch J, Martin KJ, Slatopolsky E: Absence of biological effects of oxidized parathyroid hormone-(1-34) in dogs and rats. Endocrinology 1984;115:2375-2378.

10 Horiuchi N: Effects of oxidation of human parathyroid hormone on its biological activity in continuously infused, thyroparathyroidectomized rats. J Bone Miner Res 1988;3:353-358.

11 Zull JE, Smith SK, Wiltshire R: Effect of methionine oxidation and deletion of amino-terminal residues on the conformation of parathyroid hormone. Circular dichroism studies. J Biol Chem 1990;265:5671-5676.

12 Hocher B, Armbruster FP, Grön HJ, Stoeva S, Reichetzeder C, Grön HJ, Lieker I, Khadzhynov D, Slowinski T, Roth HJ: Measuring parathyroid hormone (PTH) in patients with oxidative stress - do we need a fourth generation parathyroid hormone assay? PLoS One 2012;7:e40242.

13 Tepel M, Armbruster FP, Grön HJ, Scholze A, Reichetzeder C, Roth HJ, Hocher B: Oxidation Matters when Measuring Parathyroid Hormone in Patients on Dialysis. Abstract SA-P0729; ASN Kidney Week; available at www.asn-online.org, 2012.

14 Berman HM, Westbrook J, Feng Z, Gilliland G, Bhat TN, Weissig H, Shindyalov IN, Bourne PE: The Protein Data Bank. Nucleic Acids Res 2000;28:235-242.

15 Jin L, Briggs SL, Chandrasekhar S, Chirgadze NY, Clawson DK, Schevitz RW, Smiley DL, Tashjian AH, Zhang F: Crystal structure of human parathyroid hormone 1-34 at 0.9-A resolution. J Biol Chem 2000;275:2723827244.

16 SYBYL-X 2 TI, 1699 South Hanley Rd., St. Louis, Missouri, 63144, USA

17 Pioszak AA, Xu HE: Molecular recognition of parathyroid hormone by its G protein-coupled receptor. Proc Natl Acad Sci USA 2008;105:5034-5039.

18 Emsley P, Lohkamp B, Scott WG, Cowtan K: Features and development of Coot. Acta Crystallogr D Biol Crystallogr 2010;66:486-501.

19 Winn MD, Ballard CC, Cowtan KD, Dodson EJ, Emsley P, Evans PR, Keegan RM, Krissinel EB, Leslie AG, McCoy A, McNicholas SJ, Murshudov GN, Pannu NS, Potterton EA, Powell HR, Read RJ, Vagin A, Wilson KS: Overview of the CCP4 suite and current developments. Acta Crystallogr D Biol Crystallogr 2011;67:235242.

20 Schrodinger, LLC: The PyMOL Molecular Graphics System, Version 1.3r1, 2010.

21 Laskowski RA: PDBsum new things. Nucleic Acids Res 2009;37:D355-359.

22 Querfeld U, Anarat A, Bayazit AK, Bakkaloglu AS, Bilginer Y, Caliskan S, Civilibal M, Doyon A, Duzova A, Kracht D, Litwin M, Melk A, Mir S, Sözeri B, Shroff R, Zeller R, Wühl E, Schaefer F, 4C Study Group: The Cardiovascular Comorbidity in Children with Chronic Kidney Disease (4C) study: objectives, design, and methodology. Clin J Am Soc Nephrol 2010;5:1642-1648.

23 Pang PK, Yang MC, Keutmann HT, Kenny AD: Structure activity relationship of parathyroid hormone: separation of the hypotensive and the hypercalcemic properties. Endocrinology 1983;112:284-289.

24 Pitts TO, Puschett JB, Rose ME, Zull JE: Effects of selective oxidation of 1-34 bovine parathyroid hormone on its renal actions in the rabbit. Miner Electrolyte Metab 1989;15:267-275.

25 Frelinger AL, 3rd, Zull JE: The role of the methionine residues in the structure and function of parathyroid hormone. Arch Biochem Biophys 1986;244:641-649.

26 Di Bella FP, Dousa TP, Miller SS, Arnaud CD: Parathyroid hormone receptors of renal cortex: specific binding of biologically active. 125I-labeled hormone and relationship to adenylate cyclase activation. Proc Natl Acad Sci USA 1974;71:723-726.

27 Chu LL, Forte LR, Anast CS, Cohn DV: Interaction of parathyroid hormone with membranes of kidney cortex: degradation of the hormone and activation of adenylate cyclase. Endocrinology 1975;97:10141023.

28 McIntosh CH, Hesch RD: Characterization of the parathyrin receptor in renal plasma membranes by labelled hormone and labelled antibody binding techniques. Biochim Biophys Acta 1976;426:535-546.

29 Martin KJ, Freitag JJ, Conrades MB, Hruska KA, Klahr S, Slatopolsky E: Selective uptake of the synthetic amino terminal fragment of bovine parathyroid hormone by isolated perfused bone. J Clin Invest 1978;62:256-261.

-30 Freitag JJ, Martin KJ, Conrades MB, Slatopolsky E: Metabolism of parathyroid hormone by fetal rat calvaria. Endocrinology 1979;104:510-516.

-31 Hruska KA, Korkor A, Martin K, Slatopolsky E: Peripheral metabolism of intact parathyroid hormone. Role of liver and kidney and the effect of chronic renal failure. J Clin Invest 1981;67:885-892. 


\section{Kidney \\ Blood Pressure Research}

Kidney Blood Press Res 2013;37:240-251

\begin{tabular}{l|l}
\hline DOI: $10.1159 / 000350149$ & (c) 2013 S. Karger AG, Basel
\end{tabular}

Published onlıne: July 14, 2013

www.karger.com/kbr

Hocher/Oberthür/Slowinski/Querfeld/Schaefer/Doyon/Tepel/Roth/Grön/Reichetzeder/ Betzel/Armbruster: Non-oxidized PTH in patients with chronic renal failure

-32 Pang PK, Yang MC, Kenny AD, Tenner TE, Jr:: Structure and vascular activity relationship of parathyroid hormone and some hypotensive peptides. Clin Exp Hypertens A 1982;4:189-199.

33 Fox J, Scott M, Nissenson RA, Heath H, 3rd: Effect of plasma calcium concentration on the metabolic clearance rate of parathyroid hormone in the dog. J Lab Clin Med 1983;102:70-77.

-34 Rafferty B, Zanelli JM, Rosenblatt M, Schulster D: Corticosteroidogenesis and adenosine 3'. 5'monophosphate production by the amino-terminal (1-34) fragment of human parathyroid hormone in rat adrenocortical cells. Endocrinology 1983;113:1036-1042.

-35 Yen YC, Yang MC, Kenny AD, Pang PK: Parathyroid hormone (PTH) fragments relax the guinea-pig trachea in vitro. Can J Physiol Pharmacol 1983;61:1324-1328.

36 Shew RL, Kenny AD, Pang PK: Uterine relaxing action of parathyroid hormone: effect of oxidation and methionine substitution. Proc Soc Exp Biol Med 1984;175:444-448.

37 Miller SC, Kenny AD: Activation of avian medullary bone osteoclasts by oxidized synthetic parathyroid hormone (1-34). Proc Soc Exp Biol Med 1985;179:38-43.

38 Barling PM, Bibby NJ: Study of the localization of [3H] bovine parathyroid hormone in bone by light microscope autoradiography. Calcif Tissue Int 1985;37:441-446.

-39 Yee JA: Stimulation of alkaline phosphatase activity in cultured neonatal mouse calvarial bone cells by parathyroid hormone. Calcif Tissue Int 1985;37:530-538.

40 Shiraki M, Gee MV, Baum BJ, Roth GS: Parathyroid hormone stimulates phosphate efflux through an apparently adenosine 3'.5'-monophosphate-independent process in rat parotid cell aggregates. Endocrinology 1986;118:2009-2015.

-41 Hong BS, Yang MC, Liang JN, Pang PK: Correlation of structural changes in parathyroid hormone with its vascular action. Peptides 1986;7:1131-1135.

-42 Pang PK, Yang MC, Tenner TE, Jr., Kenny AD, Cooper CW: Cyclic AMP and the vascular action of parathyroid hormone. Can J Physiol Pharmacol 1986;64:1543-1547.

-43 Levy J, Gavin JR, 3rd, Morimoto S, Hammerman MR, Avioli LV: Hormonal regulation of (Ca2+ + Mg2+) ATPase activity in canine renal basolateral membrane. Endocrinology 1986;119:2405-2411.

44 Martin KJ, Finch JL, Hruska K, Slatopolsky E: Effect of biological activity of PTH on its peripheral metabolism in the rat. Kidney Int 1987;31:937-940.

-45 Helwig JJ, Yang MC, Bollack C, Judes C, Pang PK: Structure-activity relationship of parathyroid hormone: relative sensitivity of rabbit renal microvessel and tubule adenylate cyclases to oxidized PTH and PTH inhibitors. Eur J Pharmacol 1987;140:247-257.

46 Brennan DP, Levine MA: Characterization of soluble and particulate parathyroid hormone receptors using a biotinylated bioactive hormone analog. J Biol Chem 1987;262:14795-14800.

47 Pang PK, Wang R, Shan J, Karpinski E, Benishin CG: Specific inhibition of long-lasting. L-type calcium channels by synthetic parathyroid hormone. Proc Natl Acad Sci USA 1990;87:623-627.

-48 Nabuchi Y, Fujiwara E, Ueno K, Kuboniwa H, Asoh Y, Ushio H: Oxidation of recombinant human parathyroid hormone: effect of oxidized position on the biological activity. Pharm Res 1995;12:2049-2052. 